\title{
Trend in GHG Emissions from Northeast and West Coast Regions of India
}

\author{
Tongdi Jamir ${ }^{1}$ and Uday Shankar De ${ }^{2}$ \\ ${ }^{I}$ Department of Environmental Science, University of Pune, India \\ ${ }^{2}$ Visiting faculty, Central Training Institute, Indian Meteorological Department, India

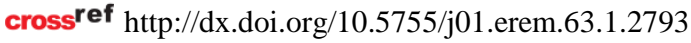

(received in November, 2012, accepted in March, 2013)

\begin{abstract}
Climate change due to increasing concentrations of greenhouse gases (GHGs) has emerged as a serious global environmental issue. An attempt has been made to assess the GHG emissions in two geographical regions of India i.e. the Northeast Region (NER) and the West coast Region (WCR) during the period of 1980-2005. The analysis reveals an increasing trend in GHG emissions from the study regions except for $\mathrm{CH}_{4}$, which shows a decreasing trend in Goa and Kerala. As far as state wise GHG emissions are concerned; Assam ranks first in $\mathrm{CO}_{2}, \mathrm{CH}_{4}$ and $\mathrm{N}_{2} \mathrm{O}$ emissions from the NER. Konkan ranks first in $\mathrm{CO}_{2}$ and $\mathrm{CH}_{4}$ emissions, while Kerala ranks first in $\mathrm{N}_{2} \mathrm{O}$ emissions representing the WCR. Analysis of the compounded annual growth rate reveals higher for the WCR in $\mathrm{CO}_{2}$ and $\mathrm{CH}_{4}$ emissions except $\mathrm{N}_{2} \mathrm{O}$ where the NER remains the highest. In order to find the association between GHG emissions and climatic response, the mean air temperature for 26 stations in both regions were subjected to trend analysis. The findings show warming trends in the mean air temperature over a majority of the stations indicating a possible role by increased GHGs. Further, the analysis reveals a positive correlation of population and GHG emissions significantly at $99 \%$ for both the regions.
\end{abstract}

Keywords: Climate Change, Correlation, Greenhouse gas, Population, Trend.

\section{Introduction}

Climate change due to increasing concentrations of greenhouse gases (GHGs) in the atmosphere has emerged as a serious global environmental issue and poses a threat and challenge to mankind. The impact of human activities on climatic system is indisputable. But these socio-economic activities are related to the development which is also a key to the living being of global population. According to the World Meteorological Organization, the globally averaged mixing ratios of $\mathrm{CO}_{2}, \mathrm{CH}_{4}$ and $\mathrm{N}_{2} \mathrm{O}$ reached a new height in 2008 with $\mathrm{CO}_{2}$ at 385.2 ppm, $\mathrm{CH}_{4}$ at 1797 $\mathrm{ppb}$ and $\mathrm{N}_{2} \mathrm{O}$ at $321.8 \mathrm{ppb}$. According to IPCC (1996), $\mathrm{CO}_{2}, \mathrm{CH}_{4}$ and $\mathrm{N}_{2} \mathrm{O}$ are the key GHGs that contribute to $60 \%, 15 \%$ and $5 \%$, respectively, towards global warming.

Several researchers have documented the effects relating to emissions of $\mathrm{CO}_{2}, \mathrm{CH}_{4}$ and $\mathrm{N}_{2} \mathrm{O}$ from energy and agricultural sectors on global and regional context. Many researchers in India have estimated emission inventories of different GHGs (Mitra 1991;
ALGAS 1998; NATCOM 2004). Garg et al. (2001a) reported the emission growth of $6.3 \%, 1.2 \%$, and $3.3 \%$ from $\mathrm{CO}_{2}, \mathrm{CH}_{4}$ and $\mathrm{N}_{2} \mathrm{O}$, respectively, in India during the period of 1990 - 1995. Gupta (2002) found an increase in $\mathrm{CH}_{4}$ flux by 1.7 times relative to low soil organic carbon in the rice ecosystem. Investigation on $\mathrm{N}_{2} \mathrm{O}$ emissions from India reveals that during the last 40 years, $\mathrm{N}_{2} \mathrm{O}$ has increased by $\sim 6.1$ times from $\sim 0.048$ to $0.294 \mathrm{Tg}$ (Prasad et al. 2003). On the other hand, maximum $\mathrm{CH}_{4}$ is emitted from indigenous male cattle as reported by Singhal et al. (2005). In the study on the GHG emission scenario, Shukla (2006) found a secular increase in $\mathrm{CO}_{2}$ and $\mathrm{CH}_{4}$ emissions in all the scenarios; however $\mathrm{N}_{2} \mathrm{O}$ grows faster than $\mathrm{CH}_{4}$ emissions. In the findings of Sharma (2006), GHG emission grew at the rate of 4\% per annum during the year 1990 and 2000. Further, Garg et al. (2006) reported that during the period of 1985 to 2005 the Compound annual growth rate (CAGR) was 5.3, 0.8 and $3.2 \%$ for the $\mathrm{CO}_{2}, \mathrm{CH}_{4}$ 
and $\mathrm{N}_{2} \mathrm{O}$, respectively, in the country. The latest report on GHG emission for the country reveals a significant growth in cement production $(6.0 \%)$, electricity generation $(5.6 \%)$ and transport $(4.5 \%)$ during 1994 2007. However, there is a decrease in $\mathrm{CH}_{4}$ emissions from agricultural sector. GHG emissions from energy, industry, agriculture, and waste sectors constituted $58 \%, 22 \%, 17 \%$ and $3 \%$ of the net $\mathrm{CO}_{2}$ eq emissions, respectively (MoEF 2010).

Ogbeide (2010) developed an economic model to reduce $\mathrm{CO}_{2}$ emissions with the least cost from cement plants, thereby reducing the emission by $23.6 \%$ per tonne of cement produced. Matson (2003) investigated $\mathrm{N}_{2} \mathrm{O}$ flux from polluted aquatic systems in low-latitude regions. They found $\mathrm{N}_{2} \mathrm{O}$ fluxes during green algae blooms and canals receiving pigfarm and urban inputs. Yan et al. (2005) developed a statistical model to relate $\mathrm{CH}_{4}$ flux in the rice-growing season, the results showed that organic amendment and water regime were the top two controlling variables. The annual growth of $\mathrm{CH}_{4}$ from enteric fermentation and manure management in China were $2.2 \%$ and $3.5 \%$, while it is $3.0 \%$ for $\mathrm{N}_{2} \mathrm{O}$ emission from manure management as reported by Zhou et al. 2007. Yang et al. (2009) have investigated the $\mathrm{CH}_{4}$ and $\mathrm{N}_{2} \mathrm{O}$ emissions from paddy fields in Taiwan and have found that intermittent irrigation and appropriate application of nitrogen fertilizer significantly reduces $\mathrm{CH}_{4}$ emissions. Zhang et al. (2009) reported that a higher $\mathrm{CH}_{4}$ emission in China was linked to gleyed paddy and alluvial plain soils while the lowest emission rate is associated with degleyed paddy and low mountainous-hilly soils.

Industrialization, urbanization, population growth and exploitations of natural resources will have an impact on the environment. The continued increase in the concentration of GHGs in the atmosphere will lead to climate change affecting humanity, flora and fauna. These two studied regions have huge coal, oil and natural gas reserves for thermal and cement plants generation, followed by a growth in number of vehicles, too. These regions experience tropical rainy climate and hence fit for paddy cultivation. The presence of tribal population with different religious and ethnic background has made the livestock rearing the dominant economic activity. Considering the above situation, estimation of GHG is essential, which will ultimately have an impact on the climate. In the light of the above discussions two extreme regions of India, namely the WCR and NER, (Figure 1) have been selected for this study.

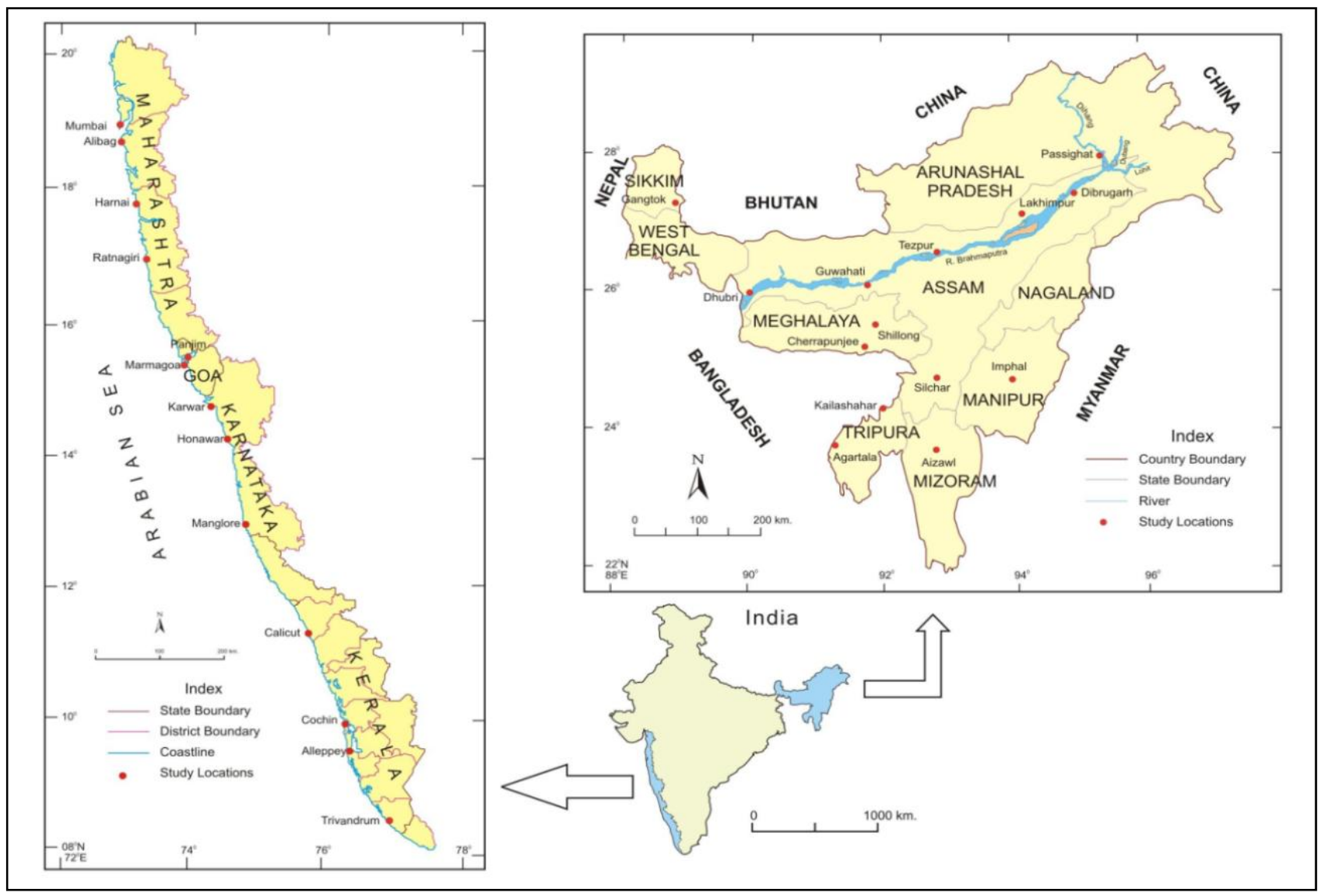

Fig.1. Study Area of NER and WCR

In the earlier scientific studies trends were not discussed, in this paper an attempt has been made to examine the trend in GHG emissions and climate response in terms of a climatic parameter. This has been achieved by the following objectives: 
- $\quad$ to assess the trends in GHG emissions from the main sources on annual scale;

- $\quad$ to correlate the population growth with that of the GHG emissions ;

- to evaluate the GHG emissions and climate response using a climatic parameter.

\section{Materials and methods}

Annual activity data of coal consumption (cement and thermal power plants), diesel and petrol (transportation), livestock (population), paddy cultivation (hectares), liquefied petroleum gas (tonnes) and fuel wood consumption (tonnes), nitrogen fertilizers (tonnes) were collected for estimating $\mathrm{CO}_{2}, \mathrm{CH}_{4}$ and $\mathrm{N}_{2} \mathrm{O}$. The activity data from various sectors during the period of 1980-2005 were collected from the published documents of the Government of India, the State Government and reputed organizations such as the Centre for Monitoring Indian economy (CMIE), the Fertilizers Association of India (FAI), the Agricultural Statistics at a glance (Ministry of Agriculture, the Government of India), TEDDY - The Energy Data Directory and Yearbook. The activity data prior to 1980 were insufficient from most of the sectors, therefore the data for this study were used from 1980 onwards.

To estimate the GHG emissions from various sectors the IPCC 1996 methodology was used. The IPCC 1996 methodology implies that the activity data for a source category are multiplied by a respective emission factor to obtain emissions from that source category for a specific gas. The indigenously developed emission factors are used in this study. However, the IPCC default emission factor was used where the emission factor was not available. To calculate the total emission of a gas from all its source categories, the emissions are summed up over all source categories as follows: (Eq.1)

$$
\text { Emissions of a Gas }=\Sigma \text { Category } A x E F
$$

where,

Emissions of a Gas = emissions of a given gas from all its source categories;

$\mathrm{A}=$ amount of individual source category utilized;

$\mathrm{EF}=$ emission factor of a given gas by type of source category.

For calculating $\mathrm{CO}_{2}, \mathrm{CH}_{4}$ and $\mathrm{N}_{2} \mathrm{O}$ emissions from energy, transportation and agricultural sectors, respectively, the emission factors are given below (Table 1 a-e).

Table.1 (a). Emission Factors for Estimating $\mathrm{CO}_{2}$

\begin{tabular}{||l|l|l|l|l||}
\hline Sector & Types & NCV & Emission factor & References \\
\hline & & Energy sector & & \\
\hline Cement plant & Non-coking coal & $19.63 \pm 0.4 \mathrm{TJ} / \mathrm{Kt}$ & $26.13 \mathrm{t} \mathrm{CO}_{2} / \mathrm{TJ}$ & Natcom, 2004 \\
\hline Thermal power plant & Non-coking coal & $19.63 \pm 0.4 \mathrm{TJ} / \mathrm{Kt}$ & $26.13 \mathrm{t} \mathrm{CO}_{2} / \mathrm{TJ}$ & Natcom, 2004 \\
\hline & & Transport sector & & \\
\hline 2/3\& 4 Wheeler & Petroleum & $44.80 \mathrm{TJ} / 10^{3}$ tons & $18.9 \mathrm{t} \mathrm{C/TJ}$ & IPCC, 1996 \\
\hline LCV MCV \& HCV & Diesel & $43.33 \mathrm{TJ} / 10^{3}$ tons & $20.2 \mathrm{t} \mathrm{C/TJ}$ & IPCC, 1996 \\
\hline
\end{tabular}

Note: NCV-Net Calorific Value; LCVMCV\&HCV-Light Commercial Vehicle, Medium Commercial Vehicle \& Heavy Commercial Vehicle

Table.1 (b). Emission Factors for Estimating $\mathrm{CH}_{4}$

\begin{tabular}{|c|c|c|c|}
\hline \multicolumn{4}{|c|}{$\begin{array}{r}\text { Livestock (After Singhal, K.K., et al, 2005) } \\
\end{array}$} \\
\hline Sector & Emission factor & Sector & Emission factor \\
\hline & Crossbred (Male) & & Crossbred (female) \\
\hline Adult & $34.05 \mathrm{CH}_{4} /$ head/year $\mathrm{Kg}$ & Adult & $38.83 \mathrm{CH}_{4} / \mathrm{head} /$ year Kg \\
\hline $1-2 \frac{1}{2}$ years & $19.67 \mathrm{CH}_{4} /$ head/year Kg & $1-2 \frac{1}{2}$ years & $21.31 \mathrm{CH}_{4} / \mathrm{head} /$ year $\mathrm{Kg}$ \\
\hline \multirow[t]{2}{*}{$0-1$ years } & $9.02 \mathrm{CH}_{4} / \mathrm{head} /$ year $\mathrm{Kg}$ & $0-1$ years & $9.71 \mathrm{CH}_{4} / \mathrm{head} /$ year Kg \\
\hline & Indigenous (Male) & & Indigenous (Female) \\
\hline Adult & $29.42 \mathrm{CH}_{4} /$ head/year Kg & Adult & $35.97 \mathrm{CH}_{4} / \mathrm{head} /$ year Kg \\
\hline $1-3$ years & $16.36 \mathrm{CH}_{4} /$ head/year $\mathrm{Kg}$ & $1-3$ years & $15.39 \mathrm{CH}_{4} / \mathrm{head} /$ year $\mathrm{Kg}$ \\
\hline \multirow[t]{2}{*}{$0-1$ years } & $7.60 \mathrm{CH}^{4} / \mathrm{head} /$ year $\mathrm{Kg}$ & $0-1$ years & $7.39 \mathrm{CH}_{4} / \mathrm{head} /$ year Kg \\
\hline & Buffalo (Male) & & Buffalo (Female) \\
\hline Adult & $54.28 \mathrm{CH}_{4} /$ head/year Kg & Adult & $76.65 \mathrm{CH}_{4} /$ head/year Kg \\
\hline $1-3$ years & $14.78 \mathrm{CH}_{4} / \mathrm{head} /$ year $\mathrm{Kg}$ & $1-3$ years & $17.35 \mathrm{CH}_{4} /$ head/year Kg \\
\hline $0-1$ years & $5.09 \mathrm{CH}_{4} /$ head/year $\mathrm{Kg}$ & $0-1$ years & $6.06 \mathrm{CH}_{4} /$ head/year Kg \\
\hline
\end{tabular}

To determine the trend in GHG emissions, linear regression coefficients were used (Eq.2). For finding the level of significance at 0.05 and 0.01 , Student's ttest was employed (Eq.3). Time series graphs were plotted for the entire periods of record.
This is a simple model which is expressed in the form of an equation:

$$
Y=a+b X
$$


The statistical significance was determined by the

Student's t-test in the following way:

$$
t=\sqrt{\frac{r^{2}(N-2)}{1\left(1-r^{2}\right)}}
$$

Table.1(c). Emission Factors for Estimating $\mathrm{CH}_{4}$

\begin{tabular}{|l|l|l|l|l|l||}
\hline \hline \multicolumn{2}{||l}{$\begin{array}{l}\text { Paddy cultivation (Lowland and upland) (Reference- Natcom } \\
2004)\end{array}$} & \multicolumn{2}{l||}{ Energy sector (Reference- IPCC, 1996) } \\
\hline Sector & Types & Emission factor & Sector & Types & Emission factor \\
\hline $\begin{array}{l}\text { Rice } \\
\text { cultivation }\end{array}$ & Continuously flooded & $29.2 \mathrm{~g} / \mathrm{m}^{2}(\mathrm{Avg})$ & Household & LPG & $0.2 \mathrm{~g} / \mathrm{Kg}$ \\
\hline $\begin{array}{l}\text { Rice } \\
\text { cultivation }\end{array}$ & I. Single aeration & $9.12 \mathrm{~g} / \mathrm{m}^{2}(\mathrm{Avg})$ & Household & Fuel wood & $0.006 \mathrm{Kg} \mathrm{Kg}^{-1}$ \\
\hline $\begin{array}{l}\text { Rice } \\
\text { cultivation }\end{array}$ & I. Multiple aeration & $3.6 \mathrm{~g} / \mathrm{m}^{2}(\mathrm{Avg})$ & & & \\
\hline $\begin{array}{l}\text { Rice } \\
\text { cultivation }\end{array}$ & $\begin{array}{l}\text { RF L \& U (flood } \\
\text { prone) }\end{array}$ & $\begin{array}{l}19.0 \pm 6.0 \quad \mathrm{~g} / \mathrm{m}^{2} \\
(\text { Avg) }\end{array}$ & & & \\
\hline
\end{tabular}

Note: I- Intermittently, RFL-Rain fed lowland \& U-Upland

Table.1 (e). Emission Factors for Estimating $\mathrm{N}_{2} \mathrm{O}$

\begin{tabular}{|l|l|l|l||}
\hline \multicolumn{4}{|c||}{ Agriculture sector } \\
\hline Sector & Types & Emission factor & References \\
\hline Agriculture & Nitrogen Fertilizer & $0.0125 \mathrm{Kg} \mathrm{N}^{2} \mathrm{O}-\mathrm{N} / \mathrm{Kg}$ & IPCC,1996 \\
\hline
\end{tabular}

Apart from the activity data for estimating the GHG emission, meteorological data the mean air temperature have been utilised in the study. Annual and seasonal time series were prepared from the monthly values. The monthly mean temperatures for 13 stations each in the NER and the WCR during the period ranging from 1901-2006 were used. The monthly mean air temperature values pertaining to winter (January-February), pre-monsoon/summer (March-May), monsoon (June-September), postmonsoon (October-December) and annual values were calculated over each station. The data were obtained from the Indian Meteorological Department (IMD), Pune, India. To determine the significance of the trend, Mann Kendall tau rank correlation coefficient (Kendall's $\tau$ ) was used.

The Kendall tau rank correlation coefficient (Eq. 4) has been used to analyse the trends in temperature and rainfall parameters. The trends are tested at $95 \%$ and 99\% level of confidence.

Relative values of all the time series under analysis are arranged by their ranks in a way that each term is assigned a number ranging from 1 to $\mathrm{N}$ (4).

$$
p=\sum_{i-1}^{n-1} n_{i}
$$

Where

$\mathrm{n}_{\mathrm{i}}=$ number of later terms whose value exceeds $\mathrm{n}_{\mathrm{i}}$ (the elements) or $\mathrm{k}_{\mathrm{i}}$ (the rank); then (5)

$r=\left\{\frac{4 p}{N(N-1)}\right\}-1$

If the value of ' $r$ ' is +1 , there is a perfect systematic positive trend, and if ' $r$ ' is -1 , there is a systematic negative trend. The value of ' $r$ ' will be very near to zero when no significant trend is seen. The value of ' $r$ ' thus can be used as the basis of a significant test by comparing it with (6)

$$
r(t)= \pm t_{g} \sqrt{\frac{4 N+10}{9 N(N-1)}}
$$

$\mathrm{N}$-total number of elements in the time series, where $\mathrm{t}_{\mathrm{g}}$ is the desired probability point of the Gaussian normal distribution. In the present study, $\mathrm{t}_{\mathrm{g}}$ at $95 \%$ and $99 \%$ probability point has been taken for comparison. The results are discussed in the following paragraphs.

\section{Results and discussion}

\subsection{Trends in carbon dioxide emissions}

The annual emissions of $\mathrm{CO}_{2}$ from different sources such as thermal power plant, cement plant and transportation sectors are reported in Table 2. In the NER, thermal and cement power plant are located at Assam only, these data are not available for the rest of the states, for this reason petrol and diesel consumption data have been used.

The Table 2 indicates an increasing trend in $\mathrm{CO}_{2}$ emissions in all the Northeast states. The trends are significant at $99 \%$ level except for Assam. The maximum emissions are from the state of Assam where it is increasing by $48,597 \mathrm{Gg} /$ year, while the lowest emission comes from Mizoram (2,013 $\mathrm{Gg} /$ year). The maximum $\mathrm{CO}_{2}$ in Assam is attributed by the emission from thermal plant. For the rest of the states, the major emissions come from transportations sector consuming diesel followed by petrol. The least 
amount of emission from Mizoram can be ascribed to the less number of vehicles as compared to the rest of the states. During the last 25 years, every year 1,011motor vehicles has increased in Mizoram as compared to 20,159 in Assam.

Table. 2

Trends in $\mathrm{CO}_{2}$ Emissions (NER \& WCR)

\begin{tabular}{|c|c|c|c|c|c|c|c|}
\hline & \multicolumn{4}{|c|}{ List of sectors } & \multicolumn{3}{|c|}{ Total $\mathrm{CO}_{2}$ emissions } \\
\hline NER & TPP & $\mathrm{CP}$ & Petrol & Diesel & Slope & $\mathrm{R}^{2}$ & $\mathrm{SL}$ \\
\hline $\mathrm{AP}$ & & & 1458.x & 3751.x & 5210.x & 0.948 & $+* *$ \\
\hline Assam & $16012 x$ & 2393.x & 6233.x & 17839x & $48597 x$ & 0.310 & $+* *$ \\
\hline Meghalaya & & & 2222.x & $11553 x$ & $13776 x$ & 0.916 & $+* *$ \\
\hline Nagaland & & & $815.8 \mathrm{x}$ & 1886.x & $2702 . \mathrm{x}$ & 0.961 & $+* *$ \\
\hline Manipur & & & $861.3 \mathrm{x}$ & 1413.x & $2274 . x$ & 0.917 & $+* *$ \\
\hline Mizoram & & & $819.5 x$ & 1193.x & 2013.x & 0.949 & $+* *$ \\
\hline Tripura & & & 1277.x & 2731.x & 4008.x & 0.986 & $+* *$ \\
\hline Sikkim & & & $496.8 x$ & $2230 x$ & $2726 . x$ & 0.796 & $+* *$ \\
\hline WCR & & & & & & & \\
\hline Konkan & $38844 x$ & 1914.x & $30095 x$ & $80480 x$ & $50141 x$ & 0.993 & $+* *$ \\
\hline Goa & & & $6531 . \mathrm{x}$ & $17436 x$ & $23968 x$ & 0.953 & $+* *$ \\
\hline $\mathrm{CK}$ & & & 3993.x & $13894 x$ & $17888 x$ & 0.982 & $+* *$ \\
\hline Kerala & & $3360 . x$ & $42587 x$ & $92700 x$ & $13864 x$ & 0.982 & $+* *$ \\
\hline
\end{tabular}

Note: AP-Arunachal Pradesh, CK-Coastal Karnataka, TTP-Thermal Power plant, CP-Cement Plant, SL-Significant level, * Indicate $0.05 \%$ \& ** $0.01 \%$ Significant level

In the WCR, the $\mathrm{CO}_{2}$ emissions from various sectors have been computed for the four sub-regions, namely Konkan, Goa, Coastal Karnataka (CK) and Kerala. In this region, thermal power stations are situated at Konkan area only, while the cement plants are found in Konkan and Kerala. These data are not available for Goa and CK, thus petrol and diesel consumption data have been used.

It is clear from Table 2 that all the sub-regions in the WCR indicate the trend increasing significantly by $99 \%$. The highest rate of increase is reported at
Konkan $(50,141 \mathrm{Gg} /$ year $)$, while the lowest is contributed by Kerala $(13,864 \mathrm{Gg} /$ year $)$. The maximum increase at Konkan is attributed by the emissions from thermal plant. This can be attributed to higher consumption of electricity from the most populated Indian metro-Mumbai metropolitan area (22, 252, 912 people, 2011 Census). In addition to this, the motor vehicles in Konkan have increased at a faster rate $(89,457 /$ year) as compared to Kerala (10, 649/year).

Table. 3.

Trends in $\mathrm{CH}_{4}$ Emissions (NER \& WCR)

\begin{tabular}{|c|c|c|c|c|c|c|c|}
\hline & \multicolumn{4}{|c|}{ List of sectors } & \multicolumn{3}{|c|}{ Total $\mathrm{CH}_{4}$ emissions } \\
\hline NER & Livestock & Paddy & LPG & Fuel wood & Slope & $\mathrm{R}^{2}$ & SL \\
\hline $\mathrm{AP}$ & $207.8 x$ & $0.394 \mathrm{x}$ & $3.669 x$ & $0.037 \mathrm{x}$ & $0.716 \mathrm{x}$ & 0.994 & $+* *$ \\
\hline Assam & 4476.x & $-0.016 \mathrm{x}$ & $59.27 x$ & $0.797 x$ & $6.510 x$ & 0.961 & $+* *$ \\
\hline Meghalaya & $221.7 x$ & $0.075 \mathrm{x}$ & $3.996 x$ & $0.147 x$ & $0.529 x$ & 0.985 & $+* *$ \\
\hline Nagaland & $362.2 x$ & $0.066 \mathrm{x}$ & $4.567 x$ & $0.111 \mathrm{x}$ & $0.636 x$ & 0.921 & $+* *$ \\
\hline Manipur & $110.8 x$ & $0.012 x$ & $7.001 x$ & $0.148 x$ & $0.419 x$ & 0.972 & $+* *$ \\
\hline Mizoram & $0.262 x$ & $0.305 x$ & $6.732 x$ & $0.261 x$ & $0.485 x$ & 0.963 & $+* *$ \\
\hline Tripura & $110.3 \mathrm{x}$ & $0.824 x$ & $7.010 \mathrm{x}$ & $0.018 x$ & $1.344 \mathrm{x}$ & 0.996 & $+* *$ \\
\hline Sikkim & $-1.862 x$ & $0.031 \mathrm{x}$ & $1.493 \mathrm{x}$ & $0.037 \mathrm{x}$ & $0.079 \mathrm{x}$ & 0.901 & $+* *$ \\
\hline \multicolumn{8}{|l|}{ WCR } \\
\hline Konkan & $543.0 \mathrm{x}$ & $0.153 x$ & $221.3 x$ & $0.244 \mathrm{x}$ & $5.619 x$ & 0.940 & $+* *$ \\
\hline Goa & $-46.82 x$ & $0.594 x$ & $15.96 x$ & $0.037 x$ & $0.921 x$ & 0.92 & $+* *$ \\
\hline $\mathrm{CK}$ & $91.13 x$ & $0.531 x$ & $24.39 x$ & $0.198 x$ & $1.345 \mathrm{x}$ & 0.921 & $+* *$ \\
\hline Kerala & $-1637 . x$ & $-1.020 \mathrm{x}$ & $173.4 \mathrm{x}$ & $1.186 x$ & $2.194 \mathrm{x}$ & 0.509 & $+* *$ \\
\hline
\end{tabular}

Note: AP-Arunachal Pradesh, CK-Coastal Karnataka, SL-Significant level, * Indicate 0.05\% \& **0.01\% Significant level

\subsection{Trends in methane emissions}

Methane emissions from two important sources viz., agriculture (paddy cultivation and livestock) and energy (fuel wood and LPG) were considered. For paddy cultivation, emissions were calculated from different water regimes- rain fed, continuously flooded, intermittently flooded with single aeration and multiple aerations. On the similar line, the detailed information about emissions of $\mathrm{CH}_{4}$ from the livestock population (cattle, crossbred and buffaloes) was collected. There are two sources from which $\mathrm{CH}_{4}$ is emitted from livestock i.e., enteric fermentation and manure management. However, due to unavailability of the data from the manure management, the $\mathrm{CH}_{4}$ emissions are estimated based on enteric fermentation 
only. The state wise trend in $\mathrm{CH}_{4}$ emissions from agriculture and energy sectors are reported in Table 3. The Table indicates that all the states in the NER show an increasing trend significant at $99 \%$. The maximum rate of an increase is observed at Assam $(6.510 \mathrm{Gg} /$ year), while the lowest is at Sikkim (0.079 $\mathrm{Gg} /$ year). The increase in Assam is contributed from the paddy cultivation followed by livestock, while the emissions from fuel wood and LPG are much smaller. The smallest emission from Sikkim is due to the decline in livestock population. The detailed analysis reveals that indication of the proportion of cross bred population showing an increase is not significant, on the other hand the population of indigenous cattle and buffaloes has drastically decreased this might be responsible for the minute emission of $\mathrm{CH}_{4}$ in this state.

In the WCR, all the sub-regions show increasing trend significant at $99 \%$. The faster rate of an increase in $\mathrm{CH}_{4}$ is reported at Konkan $(5.619 \mathrm{Gg} /$ year), while the least is at Goa $(0.921 \mathrm{Gg} /$ year $)$. The major contribution in the WCR comes from livestock population. When we compare the $\mathrm{CH}_{4}$ emissions from a livestock sector, there is a bigger emission from Konkan as compared to Goa.

\subsection{Trends in nitrous oxide emissions}

The third important GHG considered in this study is $\mathrm{N}_{2} \mathrm{O}$. This emission comes from agricultural soil as a result of application of nitrogen fertilizers. The trend in $\mathrm{N}_{2} \mathrm{O}$ emissions from agriculture is computed and reported in Table 4.

Table. 4. Trends in $\mathrm{N}_{2} \mathrm{O}$ Emissions (NER \& WCR)

\begin{tabular}{||l|l|l|l||}
\hline NER & Slope & $\mathrm{R}^{2}$ & SL \\
\hline AP & $0.000 \mathrm{x}$ & 0.947 & +** $^{* *}$ \\
\hline Assam & $0.042 \mathrm{x}$ & 0.871 & +** $^{* *}$ \\
\hline Meghalaya & $0.000 \mathrm{x}$ & 0.967 & +** $^{*}$ \\
\hline
\end{tabular}

\begin{tabular}{|l|l|l|l||}
\hline Nagaland & $0.000 \mathrm{x}$ & 0.982 & +** $^{* * \mid}$ \\
\hline Manipur & $0.008 \mathrm{x}$ & 0.970 & +** $^{*}$ \\
\hline Mizoram & $0.000 \mathrm{x}$ & 0.883 & +** $^{*}$ \\
\hline Tripura & $0.003 \mathrm{x}$ & 0.946 & +** $^{*}$ \\
\hline Sikkim & $0.000 \mathrm{x}$ & 0.985 & +** $^{*}$ \\
\hline WCR & & & \\
\hline Konkan & $0.016 \mathrm{x}$ & 0.965 & +** $^{*}$ \\
\hline Goa & $0.000 \mathrm{x}$ & 0.722 & +** $^{*}$ \\
\hline CK & $0.006 \mathrm{x}$ & 0.983 & +** $^{* *}$ \\
\hline Kerala & $0.021 \mathrm{x}$ & 0.948 & +** \\
\hline \hline
\end{tabular}

Note: AP-Arunachal Pradesh, CK-Coastal Karnataka, SLSignificant level, * Indicate $0.05 \%$ \& ** $0.01 \%$ Significant level

The Table indicates that there is significant rise in $\mathrm{N}_{2} \mathrm{O}$ emission from all the states in NER, however the faster rate of an increase can be seen in Assam (0.042 $\mathrm{Gg}$ /year), while the least is found at AP, Meghalaya, Nagaland, Mizoram and Sikkim. The increase in Assam (31.5kg/per hectare) can be attributed to the high amount of nitrogen fertilizer per hectare of the net sown area as compared to the rest of the states (22.5 kg/per hectares). For the WCR, the trend analysis reveals that $\mathrm{N}_{2} \mathrm{O}$ shows an increase from all the sub-regions. The faster rate of an increase is found at Konkan $(0.016 \mathrm{Gg} /$ year $)$ with the least being at Goa $(0.000 \mathrm{Gg} /$ year $)$, this is due to the excessive use of nitrogen fertilizer in agricultural fields. The consumption of fertilizer in Maharashtra is 52.7 (representing Konkan), while in Goa it is $22 \mathrm{~kg} / \mathrm{per}$ hectares of nitrogen.

\subsection{Compounded annual growth rate (CAGR) in GHG emissions}

Carbon dioxide. CAGR of $\mathrm{CO}_{2}$ emissions from energy (thermal plant and cement plant) and transportation sectors (petroleum and diesel) for the NER and WCR are reported in Table 5.

Table.5. Growth rate of $\mathrm{CO}_{2}, \mathrm{CH}_{4}$ and $\mathrm{N}_{2} \mathrm{O}$ Emissions (NER \& WCR)

\begin{tabular}{|c|c|c|c|c|c|c|c|c|c|c|c|}
\hline & \multicolumn{5}{|c|}{$\mathrm{CO}_{2}$} & \multicolumn{5}{|c|}{$\mathrm{CH}_{4}$} & $\mathrm{~N}_{2} \mathrm{O}$ \\
\hline NER & $\mathrm{CP}$ & $\mathrm{TP}$ & Petrol & Diesel & $\begin{array}{l}\text { TE(Gg) } \\
\text { CAGR }\end{array}$ & Paddy & Livestock & LPG & $\begin{array}{l}\text { Fuel } \\
\text { Wood }\end{array}$ & $\begin{array}{l}\text { TE(Gg) } \\
\text { CAGR }\end{array}$ & $\begin{array}{l}\text { TE }(\mathrm{Gg}) \\
\text { CAGR }\end{array}$ \\
\hline AP & & & 8.0 & 5.3 & 5.94 & 1.94 & 2.4 & 9.86 & 2.88 & 2.3 & 10.07 \\
\hline Assam & 5.6 & 2.4 & 4.7 & 3.7 & 2.95 & -0.01 & 1.8 & 19.34 & 2.94 & 0.9 & 10.76 \\
\hline Meghalaya & & & 6.5 & 8.3 & 7.7 & 0.41 & 1.24 & 7.77 & 2.87 & 1.19 & 3.39 \\
\hline Nagaland & & & 4.9 & 4.6 & 4.75 & 0.48 & 5 & 11.13 & 2.87 & 1.81 & 8.67 \\
\hline Manipur & & & 4.7 & 3.3 & 3.85 & 0.05 & 0.88 & 12.49 & 2.87 & 0.85 & 8.49 \\
\hline Mizoram & & & 5.0 & 3.9 & 4.28 & 2.14 & 00 & 12.33 & 2.88 & 2.6 & 12.33 \\
\hline Tripura & & & 8.6 & 4.7 & 5.71 & 2.85 & 0.65 & 12.78 & 2.87 & 2.35 & 8.28 \\
\hline Sikkim & & & 8.1 & 12.3 & 10.94 & 1.17 & -0.03 & 6.2 & 2.85 & 0.88 & 2.51 \\
\hline WCR & & & & & & & & & & & \\
\hline Konkan & 3.6 & 10.8 & 6.1 & 4.4 & 6.64 & 0.31 & 0.61 & 10.42 & 2.88 & 3.09 & 5.71 \\
\hline Goa & & & 8.5 & 5.4 & 5.59 & 2.02 & -1.07 & 16.40 & 2.88 & 2.43 & 1.62 \\
\hline $\mathrm{CK}$ & & & 6.3 & 6.3 & 6.34 & 1.47 & 0.24 & 16.28 & 2.88 & 1.57 & 5.6 \\
\hline Kerala & 4.1 & & 6.9 & 5.6 & 5.93 & -1.04 & -2.16 & 18.91 & 2.88 & 1.31 & 2.55 \\
\hline
\end{tabular}

Note: AP-Arunachal Pradesh, CK-Coastal Karnataka, CP-Cement Plant, TP-Thermal Plant, TE-Total Emissions; CAGRCompounded Annual Growth Rate 
The above Table indicates that CAGR of the total $\mathrm{CO}_{2}$ emissions from different states in NER depicts the highest rate of $10.9 \%$ increase at Sikkim, while the lowest is observed in Assam (2.95\%). The highest growth rate can be attributed to the $\mathrm{CO}_{2}$ emissions from the consumption of diesel $(12.3 \%)$. Further, there is a substantial increase in transportation (663vehicles/year) at Sikkim, which contributes to $\mathrm{CO}_{2}$ emissions. While the lower rate of growth in Assam can be attributed to the decrease in emissions from thermal power plant $(2.4 \%)$, which is due to the closing down of the plants. The thermal plant boilers are corroded due to high sulphur content in the coal; there are also difficulties in transportation of coal, high cost of production and mechanical problems. The above Table also reveals that in Assam, the growth rate is higher for cement plant $(5.6 \%)$ as compared to other sectors; this is also reflected in the production of cement. From Table 5, it is observed that there is a faster growth rate in petrol as compared to diesel for all the states except Sikkim, where that of diesel increased by $12.3 \%$. The highest growth rate of $8.6 \%$ in petrol is reported at Tripura, while the lowest $4.7 \%$ is at Assam and Manipur.

In the WCR, the total emission growth rate is highest at Konkan $(6.64 \%)$, while the lowest is reported at Goa $(5.59 \%)$. This increase is due to thermal power plant $(10.8 \%)$, whereas at Goa, it is due to the diesel consumption $(5.4 \%)$. As in NER, WCR also behaves in the same pattern, the maximum growth rate is found in petrol followed by diesel. The highest growth rate in petrol is reported at Goa $(8.5 \%)$, while the lowest at Konkan $(6.1 \%)$. It is to be noted that the $\mathrm{CO}_{2}$ emissions from petrol consumption are increasing by $8.5 \%$ per year at Goa, the same can be supported by the vehicles population, which has increased in leaps and bounds (18, 155/year).

Methane. CAGR of $\mathrm{CH}_{4}$ emissions estimated from two important sources - agriculture (paddy cultivation and livestock) and energy (fuel wood and LPG) are reported in Table 5. The above Table indicates that $\mathrm{CH}_{4}$ emission growth rates are highest at Tripura $(2.35 \%)$, while Sikkim accounts for the lowest $(0.88 \%)$. The highest growth rate in Tripura can be attributed to the LPG $(12.78 \%)$, whereas for Sikkim it is due to the decrease in livestock rearing ($0.03 \%$ ). Amongst different sources of the $\mathrm{CH}_{4}$ emissions; LPG accounts for the highest growth rate, where it varies between $19.34 \%$ per annum at Assam to $6.2 \%$ per annum at Sikkim. The faster growth rate is due to the phenomenal increase in the decadal population growth $(18.85 \%)$ (census 2001$)$.

In the WCR (Table 5), CAGR is highest at Konkan (3.09\%/year) and lowest at Kerala (1.31\%/year). The higher growth is ascribed to an increase in LPG $(10.42 \%)$, while the lowest is due to the decrease in paddy $(-1.04 \%)$ and livestock rearing $(-2.16 \%)$. Amongst different sources of $\mathrm{CH}_{4}$ emissions the highest growth rate is noticed in LPG sectors, where it ranges from $10.42 \%$ to $18.91 \%$ at Konkan and Kerala, respectively. The growth rate at Konkan can be attributed to the high population of Mumbai Metropolitan Area. The growth rate from livestock population shows decrease by $-2.16 \%$ at Kerala to $-1.06 \%$ at Goa. There has been a drastic reduction in the availability of fodder for cattle, thereby restricting the number of cattle (Krishnakumar R 2003).

In the case of paddy cultivation, there is a decrease in the growth rate at Kerala by $-1.04 \%$. This can be attributed to the changes in agricultural land use, where the rice area dropped by $60 \%$ between 1975 and 2003, while the cultivation of coconut, rubber, arecanut and banana increased during 1955 to 2003 (Kumar 2005). There cropping is converted into cash crops as the income from the latter is high. Apart from this, the urban area is increasing by $66 \mathrm{sq}$ $\mathrm{km} /$ year during the period from 1961 to 2001 .

Nitrous Oxide. $\mathrm{N}_{2} \mathrm{O}$ emissions come from agricultural soil due to the excess use of nitrogen fertilizers. This CAGR of $\mathrm{N}_{2} \mathrm{O}$ emission from agriculture in the NER and the WCR is reported in Table 5. The above Table shows that Mizoram accounts for the highest growth rate $(12.33 \%)$, while Sikkim denotes the lowest $(2.51 \%)$. The highest growth rate can be attributed to higher consumption of nitrogen fertilizer per hectare $(6.2 \mathrm{~kg})$, while the lowest $(2.5 \mathrm{~kg})$ is due to the practice of traditional system of agriculture. Apart from this, there is a number of factors limiting the expansion of fertilizer use - defective distribution system, poor transport \& communication system and inadequate institutional credit. In the WCR, the examination of CAGR reveals a faster rate of an increase in $\mathrm{N}_{2} \mathrm{O}$ at Konkan (5.71). This is due to the higher consumption of nitrogen fertilizer per hectare $(107.4 \mathrm{~kg} / \mathrm{ha})$, while Goa contributes to the lowest $(1.62 \mathrm{~kg})$.

\subsection{Greenhouse gas emissions and climatic response}

As observed in the earlier paragraphs, GHG emission has increased in the study regions. Generally, this increase would lead to warming on the global scale, but their regional ramifications are not fully understood. Keeping these uncertainties at the background, an attempt has been made to highlight the climate response in both regions, though it may not be fully associated with the emission growth there. For this, the mean air temperature for 13 stations each from the NER and WCR were used to find out the trend, and the results are reported in Table 6 along with the significant values. The Table indicates that 10 out of 13 stations show an increasing trend in the annual mean temperature. Three stations show significantly increasing trend, while 3 stations indicate quite an opposite a significantly decreasing trend. 
Table. 6.

Trend in the mean surface air temperature (NER \& WCR)

\begin{tabular}{|c|c|c|c|c|c|c|}
\hline NER & Data period & Annual & Winter & Summer & Monsoon & $\mathrm{PM}$ \\
\hline Pasighat & $1957-1993$ & + & + & - & + & + \\
\hline Dibrugarh & $1970-2000$ & $+* *$ & + & + & + & $+* *$ \\
\hline Lakhimpur & 1954-1993 & + & + & + & + & $t^{*}$ \\
\hline Tezpur & 1940-1996 & $-* *$ & - & - & $-*$ & - \\
\hline Guwahati & $1903-2000$ & + & + & $t^{*}$ & - & $t^{*}$ \\
\hline Dhubri & $1946-1993$ & $-*$ & $-* *$ & - & + & -*** \\
\hline Silchar & 1951-1994 & $-* *$ & $-* *$ & $-* *$ & - & $-*$ \\
\hline Gantok & $1970-2000$ & + & - & - & + & + \\
\hline Shillong & $1903-2000$ & $+* *$ & $t^{*}$ & + & + & $+* *$ \\
\hline Cherrapunjee & $1903-2000$ & + & - & + & - & + \\
\hline Imphal & 1954-1998 & + & $+* *$ & + & + & + \\
\hline Kailashahar & 1959-1996 & $t^{*}$ & + & + & $t^{*}$ & $t^{*}$ \\
\hline Agartala & 1953-1992 & + & - & $-* *$ & $+* *$ & + \\
\hline \multicolumn{7}{|l|}{ WCR } \\
\hline Mumbai & 1901-2006 & $+* *$ & $+* *$ & $+* *$ & + & $+* *$ \\
\hline Alibag & 1939-2002 & $+* *$ & + & + & $+* *$ & $+* *$ \\
\hline Harnai & 1970-2002 & $t^{*}$ & + & - & $+^{*}$ & $+* *$ \\
\hline Ratnagiri & 1901-2005 & $+* *$ & $t^{*}$ & + & + & $+* *$ \\
\hline Panjim & 1964-2003 & $+* *$ & $+* *$ & $+* *$ & $+* *$ & $t^{*}$ \\
\hline Marmagoa & 1970-2001 & + & + & - & + & + \\
\hline Karwar & $1915-2003$ & $+* *$ & $+* *$ & $+* *$ & $+* *$ & $+* *$ \\
\hline Honavar & 1939-2002 & $+* *$ & $+^{*}$ & + & $+*$ & $+* *$ \\
\hline Mangalore & 1901-2004 & $+* *$ & $+* *$ & + & + & $+* *$ \\
\hline Calicut & $1901-2000$ & $+* *$ & $+* *$ & $+* *$ & $+* *$ & $+* *$ \\
\hline Cochin & $1970-2000$ & + & $+*$ & + & + & + \\
\hline Alleppey & $1944-2000$ & $+* *$ & $+* *$ & $+* *$ & + & $+* *$ \\
\hline Trivandrum & 1901-2004 & $+* *$ & $+* *$ & $+* *$ & $+* *$ & $+* *$ \\
\hline
\end{tabular}

Note: PM-Post monsoon, + - Increasing, --Decreasing, * Indicate 0.05\% \& **0.01\% Significant level

During the winter and summer seasons mixed trends (increase/decrease) are reported, however it is significant only at few stations. The monsoon season is dominated by an increasing trend in 9 stations significant at 2 , while 4 stations show a decreasing trend significant only at one. During the post monsoon season, 10 stations indicate an increasing trend in the temperature significant at 5 , while 2 out of 3 stations show a significantly decreasing trend. The NER reflects warming trends in the mean temperature over the majority of the stations indicating possible role by increased GHGs. However, there are some cool pockets, where a cooling trend is observed. This reveals that other than GHG emissions, namely, local factors such as forest cover, cloud cover and rainfall etc may affect the temperature trends on the spatial patterns.

In the WCR, all 13 stations indicate a significantly increasing trend at 11 stations. It is observed that during all seasons there is an increasing trend significant by $95 \%$ and $99 \%$ except at 2 stations during the summer season. Since GHG emission shows an increasing trend, there appears a close association with the warming during all seasons. From these assessments, it is interesting to know that the climatic parameters like the mean air temperature have changed in majority of the stations in the WCR, as compared to the NER.
Our findings are in general agreement with that of Rupa Kumar et al. (1994), where they have identified an increase in the mean temperature over India due to an increase in the maximum temperature. The trends in the mean temperature confirm the findings of Kothawale et al. (2010). In their studies on maximum and minimum temperature data over India during the period of 1901-2007 they reported that annual mean maximum and minimum temperatures showed significant warming trends of $0.51{ }^{\circ} \mathrm{C}, 0.72^{\circ} \mathrm{C}$ and $0.27^{\circ} \mathrm{C}$ (each 100 year), respectively. This warming was mainly due to the increasing temperatures in winter and post-monsoon seasons. The above researchers have concluded that the mean temperature has increased over India sub continent, however they have not identified the trend in GHG emissions and its response to climate.

\subsection{Population growth and greenhouse gas emissions}

Population is one of the primary factors influencing urbanization and industrialization, which are linked with economic growth. All of these have direct implications for energy/agricultural production and its consumption. The GHG emissions from the urban areas (e.g. industries and transportation) and rural areas (e.g., agriculture) have emerged as a more 
serious issue, because it has increased simultaneously with an increase in population. The general trend is that with the growth of the population there is an increase in economic activities and in proportion
GHG emissions also increase. The above findings also conclude that there is an increasing trend in GHG emissions from all the sources in the study areas except for $\mathrm{CH}_{4}$ in the WCR (Table 7).

Table. 7.

Trend in GHG emissions from the study regions on the Annual Scale

\begin{tabular}{||l|l|l|l||}
\hline \hline $\mathrm{CO}_{2}$ & Thermal Power Plant & $\mathrm{CH}^{4}$ & Livestock \\
\hline WCR & $\mathrm{y}=38844 \mathrm{x}+1 \mathrm{E}+06$ & WCR & $\mathrm{y}=-1.041 \mathrm{x}+223.7$ \\
\hline NER & $\mathrm{y}=16012 \mathrm{x}+3 \mathrm{E}+06$ & NER & $\mathrm{y}=5.488 \mathrm{x}+246.3$ \\
\hline & Cement Plant & & Fuel Wood \\
\hline WCR & $\mathrm{y}=8511 . \mathrm{x}+32410$ & WCR & $\mathrm{y}=1.666 \mathrm{x}+38.02$ \\
\hline NER & $\mathrm{y}=5754 . \mathrm{x}+64149$ & NER & $\mathrm{y}=1.558 \mathrm{x}+36.51$ \\
\hline & Petrol & & LPG \\
\hline WCR & $\mathrm{y}=83207 \mathrm{x}+22405$ & WCR & $\mathrm{y}=9.197 \mathrm{x}-27.32$ \\
\hline NER & $\mathrm{y}=14186 \mathrm{x}+14748$ & NER & $\mathrm{y}=1.981 \mathrm{x}-7.447$ \\
\hline & Diesel & & Paddy \\
\hline WCR & $\mathrm{y}=175598 \mathrm{x}+1 \mathrm{E}+06$ & WCR & $\mathrm{y}=1.693 \mathrm{x}+570.6$ \\
\hline NER & $\mathrm{y}=42599 \mathrm{x}+493710$ & NER & $\mathrm{y}=0.258 \mathrm{x}+138.3$ \\
\hline $\mathrm{N}_{2} \mathrm{O}$ & Nitrogen fertiliser & & \\
\hline WCR & $\mathrm{y}=0.044 \mathrm{x}+0.788$ & NER & $\mathrm{y}=0.057 \mathrm{x}-0.114$ \\
\hline
\end{tabular}

In order to understand whether there is any association of an increase in GHG and population growth; the correlation technique has been used and reported in Table 8 . This Table indicates that in the NER and WCR, $\mathrm{CO}_{2}, \mathrm{CH}_{4}$ and $\mathrm{N}_{2} \mathrm{O}$ show positive correlation with the population growth. The results are significant at $99 \%$ level in all the states. Thus, there is a link between increasing consumption, population growth and GHG emissions.

Table. 8. Correlation of $G H G$ emissions and population in the study areas

\begin{tabular}{||l|l|l||}
\hline NER & Slope & $\mathrm{R}^{2}$ \\
\hline AP & $\mathrm{y}=4.289 \mathrm{x}+49237$ & 0.945 \\
\hline Assam & $\mathrm{y}=2.827 \mathrm{x}+1 \mathrm{E}+07$ & 0.313 \\
\hline Naghalaya & $\mathrm{y}=3.417 \mathrm{x}+1 \mathrm{E}+06$ & 0.927 \\
\hline Manipur & $\mathrm{y}=22.59 \mathrm{x}-21256$ & 0.905 \\
\hline Mizoram & $\mathrm{y}=18.05 \mathrm{x}+62210$ & 0.919 \\
\hline Tripura & $\mathrm{y}=9.259 \mathrm{x}+24764$ & 0.952 \\
\hline Sikkim & $\mathrm{y}=3.608 \mathrm{x}+33454$ & 0.838 \\
\hline WCR & & \\
\hline Konkan & $\mathrm{y}=0.782 \mathrm{x}+1 \mathrm{E}+07$ & 0.982 \\
\hline Goa & $\mathrm{y}=0.700 \mathrm{x}+91750$ & 0.961 \\
\hline CK & $\mathrm{y}=3.441 \mathrm{x}+3 \mathrm{E}+06$ & 0.984 \\
\hline Kerala & $\mathrm{y}=2.255 \mathrm{x}+2 \mathrm{E}+07$ & 0.973 \\
\hline
\end{tabular}

Note: AP-Arunachal Pradesh, CK-Coastal Karnataka

Some researchers have investigated the association of population with GHG emissions. Their studies show similarities with our results. Hamilton (2000) found strong correlation between changes in population and environmental impact in OECD countries over the period of 1982-1997. Their findings show a high correlation with GHGs. Marland et al. (2007) have found that a larger population leads to greater emissions. On a global scale, the average per capita carbon dioxide emissions from fossil fuels vary hugely from nation to nation, but the general trend is that emissions grow proportionally with the growth of population.

\section{Conclusions}

In a nutshell, it can be concluded that there is an increase in GHG emissions, and this might contribute to global warming at local, regional and global levels. Further, the analysis of population growth and GHG emissions shows positive correlation. Thus, significant steps should be adapted to reduce the GHG emissions from both regions. While development is a priority for most of the regions in India and other developing countries, policy makers have to adopt eco - friendly/ green technologies.

According to the Census 2011, in the NER, the population density is highest in Assam (397) followed by Tripura (350). A decadal growth rate (2001-2011) is highest in Meghalaya (22.8\%), followed by Arunachal Pradesh (25.9\%) and Mizoram (22.8\%). In the WCR, the growth of population during the last decade (2001-2011) is less as compared to the NER, in Konkan (8.38\%), Goa (8.2\%), CK (7.28\%) and Kerala (4.9\%). However, the highest density of population is reported at Mumbai and Mumbai suburb with 48,215 and 19,255, respectively. For this reason the family welfare policy and diversification of industries in the area are needed, which will ultimately reduce the population growth rate.

The forest cover in the NER is $66 \%$ of the geographical area as against $21.05 \%$ at all India level (FSI 2011). The percentage area is high in all states except Sikkim (47.34\%) and Assam (35.28\%). In the WCR, the forest cover is lowest at Konkan $31.21 \%$ as compared to Goa (59.94\%), CK (64\%) and Kerala $(44.44 \%)$. Carbon sequestration methods like planting of tropical fast growing trees should be encouraged for offsetting the increase emissions. 
Thirdly, environmental education and awareness campaign reaching the rural and urban people will reduce environmental damages.

\section{Acknowledgements}

The authors are thankful to the Energy Research Institute, New Delhi, the Ministry of Forest and Environment and also the Ministry of Agriculture, the Government of India, New Delhi for allowing us to collect the relevant data for the present work. The authors are grateful to Sumana Bhattacharya (Winrock International, New Delhi) for fruitful discussion.

\section{References}

ALGAS.1998.India National Report on Asia Least cost greenhouse gas abatement strategy. ADB and UNDP, Manila, Philippines

Agricultural Statistics at a glance MoA. 1994-2007. Directorate of Economics and Statistics, Department of Agriculture and Cooperation (DAC), Ministry of Agriculture, Government of India

Hamilton, C. 2000. Applying the IPAT formula Population growth and greenhouse gas emissions in OECD countries- A paper to the Conference of the International Society for Ecological Economics Australian National University, 6th July 2000, The Australia Institute, Department of Premier and Cabinet, NSW.

CMIE.1996-2007. India's Energy Sector. Center for Monitoring of Indian Economy, Mumbai, India

Census of India. 2011. Provisional Population Totals India Series 1. Office of the Registrar General \& Census Commissioner, India, Government of India, New Delhi

FAI. 1993-2007. Fertilizers and Allied Agricultural Statistics. Fertilizer Association of India, New Delhi

FSI. 2011. State of the forest report 2011. Forest survey of India, Ministry of Environment and Forest, Government of India, Dehradun

Garg, A., Bhattacharya, S., Shukla, P.R. and Dadhwal, V.K. Regional and sectoral assessment of greenhouse gases emissions in India. Atmospheric Environment, 2001a, 35, p. 2679-2695. 2310(00)00414-3

Gupta Prabhat, K., Sharma, C. and Sumana Bhattacharya, Mitra. Scientific basis for establishing country greenhouse gas estimate for rice-based agriculture: An Indian case study. Nutrient Cycling in Agroecosystem, 2002, 64, p.19-31.

http://dx.doi.org/10.1023/A:1021117029359

Garg, A., Shukla, P.R. and Manmohan, Kapshe. The sectoral trends of multigas emissions inventory of India. Atmospheric Environment, 2006, 40, p. 4608-4620. http://dx.doi.org/10.1016/j.atmosenv.2006.03.045

http://www.censusindia.gov.in/census

2001/projected population. pdf.

http://en.wikipedia.org/wiki/Mumbai.

IPCC. 1996. Climate Change 1995, impacts, adaptations and mitigation of climate change. Scientific technical analysis, Intergovernmental Panel on Climate Change. Watson, R.T., Zinyowera, M.C., Moss, R.H. and Dokken, D.J. Cambridge University Press, USA
IPCC. 1996. IPCC Good Practice Guidance and Uncertainty Management in National Greenhouse Gas Inventories. Cambridge University Press, New York

Krishnakumar, R. 2003. Beef without borders. Frontline, India's National Magazine from the publishers of THE HINDU, 20, 18, August 30 - September 12.

Kumar, B.M. Land use in Kerala: changing scenarios and shifting paradigms. Journal of Tropical Agriculture, 2005, 42, p.1-12.

Kothawale, D. R., Munot, A. A. and Krishna Kumar, K. Surface air temperature variability over India during 1901-2007, and its association with ENSO. Climate Research, 2010, 42, 89-104.

http://dx.doi.org/10.3354/cr00857

Mitra, A.P. 1991. Greenhouse Gas Emission in India A Preliminary Report (Ed.). CSIR, June.

MoEF. 2010. India: Greenhouse Gas Emissions 2007. Indian network for Climate Change Assessment (INCCA), Ministry of Environment \& Forests, Government of India

Matson, P. Patterns and controls of nitrous oxide emissions from waters draining a subtropical agricultural valley. Global Biogeochemical Cycles, 2003, 17, 3, 1080, http://dx.doi.org/10.1029/2002GB001991

Marland, G., T.A. Boden, R. J. Andres, A. L. Brenkert, and C. A. Johnston. 2007. Trends: A Compendium of Data on Global Change.Carbon dioxide Information Analysis Center, Oak Ridge National Lab, US Department of Energy, Oak Ridge, Tennessee

NATCOM. 2004. India's Initial National Communication to the United Nations Framework Convention on Climate Change (UNFCCC). Ministry of Environment and Forests, New Delhi

Ogbeide, S. O. Developing an optimization model for $\mathrm{CO}_{2}$ reduction in cement production process. Journal of Engineering Science and Technology Review, 2010, 3, 1, p. 85-88.

Prasad, K.V., Ben, Stinner., Deb, Stinner., John, Cardina., Richard, Moore., Prabhat, K. Gupta., Harao, Tsuruta., Kiyoto, Tanabe., Badarinath, K.V.S. and Casey, Hoy. Trends in food production and nitrous oxide emissions from the agriculture sector in India: environmental implications. Regional Environmental Change , 2003, 3, p. 154-161. http://dx.doi.org/10.1007/s10113-002-0055-y

Rupa Kumar, K., Krishna Kumar K., and Pant G.B. Diurnal asymmetry of surface temperature trends over India. Geophysical, Research Letters, 1994, 21, 8, p. 677680. http://dx.doi.org/10.1029/94GL00007

Singhal, K.K., Madhu, Mohini., Arvind, K., Jha, Prabhat., and Gupta, K. Methane emission estimates from enteric fermentation in Indian livestock: Dry matter intake approach, Current Science, 2005, 88, p.119-127.

Shukla, P.R. India's GHG emission scenarios: Aligning development and stabilization paths. Current Science, 2006, 90, p. 384-395.

TEDDY. 1993-2007. TERI Energy Data Directory and Yearbook. The Energy and Resources Institute, New Delhi

Sharma, .S, Bhattacharya, S., and Garg, A. Greenhouse gas emissions from India: A perspective. Current Science, 2006, 90, p. 326-332

Yan, X., Yagiw, K., Akiyamaw, H., and Akimoto, H. Statistical analysis of the major variables controlling methane emission from rice fields. Global Change Biology, 2005, 11, p. 1131-1141. http://dx.doi.org/10.1111/j.13652486.2005.00976.x

Zhou, J.B., Jiang, M.M., and Chen, G.Q. Estimation of methane and nitrous oxide emission from, livestock and poultry in China during 1949-2003. Energy Policy, 2007, 35, p. 3759-3767. 
http://dx.doi.org/10.1016/j.enpol.2007.01.013

Yang, S.S., Lai, C.M., Chang, H.L., Chang, E.H., and Wei, C.B. Estimation of methane and nitrous oxide emissions from paddy fields in Taiwan. Renewable Energy, 2009, 34, p. 1916-1922.

http://dx.doi.org/10.1016/j.renene.2008.12.016

Zhang, L., Yu, D., Shi, X., Weindorf, D., Zhao, L., Ding, W., Wang, H., Pan, J., and Li, C. Quantifying methane emissions from rice fields in the Taihu Lake region, China by coupling a detailed soil database with biogeochemical model. Biogeosciences, 2009, 6, p. 739749. http://dx.doi.org/10.5194/bg-6-739-2009
Phd Tongdi Jamir - Department of Environmental Science, University of Pune, India.

E-mail: tongdi.jamir@gmail.com

Uday Shankar De - Visiting faculty, Central Training Institute, Indian Meteorological Department, Pashan, Pune, India.

E-mail: $\quad$ udayshankarde@gmail.com

\title{
Šiltnamio dujų emisijos Indijos šiaurès rytų ir vakarų pakrantės regionuose
}

\author{
Tongdi Jamir ${ }^{1}$, Uday Shankar De ${ }^{2}$ \\ ${ }^{1}$ Aplinkos mokslų fakultetas, Pune universitetas, Indija \\ ${ }^{2}$ Indijos meteorologijos skyrius, Centrinis mokymų institutas, Indija
}

(gauta 2012 m. lapkričio mèn., priimta spaudai 2013 m. kovo mèn.)

Didejjant šiltnamio efektą sukeliančių duju (GHG) emisijoms, klimato kaita tapo rimta aplinkosaugine problema. Indijos Šiaurès rytų ir vakaru pakrantès regionuose buvo stengiamasi ivertinti GHG emisiju 1980-2005 m. tendencijas. Analizès rezultatai rodo, kad GHG emisijos nuolat didejja, išskyrus CH4, kurių kiekiai mažejo Goa ir Keralos regionuose. Atlikus GHG emisiju ir temperatūros pokyčių stebèjimus, nustatyta tendencija, kad GHG emisijos daro tiesioginę ịtaką klimato kaitai. Tolesnè analizè rodo, kad nuo gyventojų daugèjimo priklauso ir GHG emisijos (99 proc). 